\title{
Estimating Excess Mortality Following Pediatric and Adolescent Cancer in the U.S.
}

AnnaLynn M. Williams, $\mathrm{PhD}^{1}$; Qi Liu, MSc ${ }^{2}$; Nickhill Bhakta, MD, MPH ${ }^{3}$; Kevin R. Krull, $\mathrm{PhD}^{1,4}$; Melissa M. Hudson, MD ${ }^{1,5}$; Leslie L. Robison, $\mathrm{PhD}^{1}$; Yutaka Yasui, $\mathrm{PhD}^{1}$

Departments of ${ }^{1}$ Epidemiology and Cancer Control, ${ }^{3} \mathrm{Global}$ Pediatric Medicine, ${ }^{4} \mathrm{Psychology}$, ${ }^{5}$ Oncology, St. Jude Children's Research Hospital, ${ }^{2}$ Department of Public Health Sciences, University of Alberta, AB Canada

Corresponding Author:

AnnaLynn Williams, PhD

Postdoctoral Research Fellow

Department of Epidemiology and Cancer Control

St. Jude Children's Research Hospital

262 Danny Thomas Place, MS 735

Memphis, TN 38105

AnnaLynn.Williams@stjude.org

Phone: 901-595-8061

Yutaka Yasui, PhD

Member

Department of Epidemiology and Cancer Control

St. Jude Children's Research Hospital

262 Danny Thomas Place, MS 735

Memphis, TN 38105

Yutaka.Yasui@stjude.org

Phone: 901-595-5893

Manuscript Word Count: 
medRxiv preprint doi: https://doi.org/10.1101/2020.12.24.20248729; this version posted December 27, 2020. The copyright holder for this preprint (which was not certified by peer review) is the author/funder, who has granted medRxiv a license to display the preprint in perpetuity.

All rights reserved. No reuse allowed without permission.

\begin{abstract}
The increasing number of long-term survivors of childhood/adolescent cancer are at-risk for premature death resulting from cancer treatment exposures. To better understand the implications of late mortality, we estimated and characterized the magnitude and temporal patterns of annual excess deaths following childhood/adolescent cancers diagnosed in 19752016 in the US using SEER 9 registries. We demonstrate for several tumor types that, despite decreasing excess deaths $<5.0$ years from diagnosis, the total number of excess deaths is not necessarily decreasing due to the growing and aging population of survivors at risk for treatment related late effects.
\end{abstract}


medRxiv preprint doi: https://doi.org/10.1101/2020.12.24.20248729; this version posted December 27, 2020. The copyright holder for this

\section{Introduction}

Significant advances over the past half century in the treatment of children and adolescents with cancer have resulted in substantial improvements in 5-year survival for the majority of cancer diagnoses. However, survivors of childhood/adolescent cancer have multiple decades after the 5-year survival benchmark where they are at elevated risk for various severe and life-threatening late effects associated with their cancer treatment.[2, 3] Therefore, it is important to measure the entire impact of childhood/adolescent cancer and its treatment on the risk of mortality across the entire lifespan. Here we considered an estimation method to characterize the number and temporal patterns of annual excess deaths following childhood and adolescent cancers diagnosed from 1975 through 2016 in the US.

\section{Methods}

\section{SEER Data Abstraction}

The "Incidence - SEER 18 Regs Research Data + Hurricane Katrina Impacted Louisiana Cases, Nov 2018 Sub (1975-2016 varying)" database of the Surveillance Epidemiology and End Results (SEER) Program of the US National Cancer Institute was used for this analysis. These data are publicly available at www.seer.cancer.gov. The data set was restricted to tumors of malignant behavior diagnosed between 1975 and 2016 among those aged <20 years at diagnosis. The data set was also restricted to the original SEER 9 registries that have surveilled cancer since 1975 (San Francisco-Oakland, Connecticut, Detroit, Hawaii, lowa, New Mexico, Seattle-Puget Sound, Utah, and Atlanta). This resulted in 49,898 malignant diagnoses. If a SEER participant had more than one diagnosis, the first diagnosis was chosen resulting in 49,354 diagnoses in 49,354 individuals. The data set was restricted to the diagnoses identified in Table 1 as we needed sufficient sample size to model disease specific survival probabilities (see below). In addition, because we needed to compare age, sex, race, calendar-year specific observed and expected mortality rates, those with unknown race were excluded $(n=416)$. In 
medRxiv preprint doi: https://doi.org/10.1101/2020.12.24.20248729; this version posted December 27, 2020. The copyright holder for this

total, 41,891 individuals were included in this analysis. While necessary for the analyses, the small number of exclusions are a limitation of our analyses as they likely result in an underestimation of the true number of excess deaths.

For 144 deaths with missing last known survival month, we made a missing-at-random assumption (i.e., missing is completely at random given the diagnosis and the diagnosis year) and imputed a single value by simple random sampling of the last known survival months from those in the same diagnosis and diagnosis year. Since 144 is less than $0.5 \%$ of the total sample, the effect of this single-value imputation is minimal on the second-order characteristics of our estimates.

\section{Calculation of Excess Deaths}

Diagnosis-specific survival probabilities by year since diagnosis were estimated from the Nelson-Aalen estimator of fitted cumulative hazards[4] using Cox proportional-hazards models: a model was fit for each diagnosis group with covariates of sex, race, and year of diagnosis (as a natural cubic spline with knots at 1980, 1988, 1996, 2004, 2011) for each of three segments of years since diagnosis, $<5.0$ years, 5.0-9.9 years, and $\geq 10.0$ years since diagnosis. For each calendar year, we estimated the number of survivors who died by summing one minus each survivor's estimated survival probability across all individuals at risk of death within the year. This model-based estimates constitute our "observed" annual numbers of death, where the modeling accounts for censoring of the SEER cancer cases. To estimate excess deaths in the SEER cohort, age-sex-race-calendar-year-specific mortality rates in the US population from the National Center for Health Statistics were used to calculate expected deaths, which were subtracted from the observed deaths. This number from the SEER-9 population was then divided by 0.094 to estimate the corresponding number in the US population (SEER-9 represents $9.4 \%$ of the US population). 
medRxiv preprint doi: https://doi.org/10.1101/2020.12.24.20248729; this version posted December 27, 2020. The copyright holder for this

\section{Results}

The primary results for all cancer sites, acute lymphoblastic leukemia, central nervous tumors, and Hodgkin lymphoma are presented elsewhere (submitted for publication). Here we present findings for other cancer sites of interest.

A total of 12,132 total excess deaths occurred among acute myeloid leukemia (AML) patients, which was the third highest number of total excess deaths behind central nervous system malignancies and acute lymphoblastic leukemia. The majority of these deaths occurred within 5 years from diagnosis (93.6\%) with a small proportion (3.5\%) occurring $\geq 10.0$ years from diagnosis reflecting the poor prognosis of childhood AML. From 1985 to 2016 the total number of excess deaths has declined, largely due to decreases in the number of excess deaths occurring $<5.0$ years from diagnosis (Figure 1). The number of excess deaths occurring $\geq 10.0$ years from diagnosis increased over this time period (17.5\% of excess deaths in 2016$)$.

A total of 9,282 excess deaths from non-Hodgkin lymphoma (NHL) occurred with $87.2 \%$ occurring within 5 years from diagnosis, $4.5 \%$ between 5.0 and 9.0 years from diagnosis, and $8.3 \%$ occurring $\geq 10.0$ years from diagnosis. Similar to $A M L$, the overall total excess deaths from NHL declined from 1985 to 2016 with excess deaths <5.0 years declining over time (Figure 1). However, this decline has stabilized in recent years with deaths between 5.0 and 9.9 years increasing over time, likely representing increases in late relapse and delayed disease progression. Ewing's sarcoma followed a similar pattern of initial decline that stabilizes over time due to increases in deaths occurring $>5.0$ years from diagnosis (Figure 1 ).

In contrast, the total excess deaths from retinoblastoma have increased from 1985 to 2016 (Figure 2). While the number of excess deaths $<5.0$ years from diagnosis has remained relatively stable, the number of excess deaths occurring $\geq 10.0$ years from diagnosis has increased over time reflecting the growing population of survivors at risk for sever and lifethreatening late effects. In $2016,27.3 \%$ of excess deaths due to retinoblastoma occurred $\geq 10$ years from diagnosis. 
medRxiv preprint doi: https://doi.org/10.1101/2020.12.24.20248729; this version posted December 27, 2020. The copyright holder for this

Osteosarcoma and germ cell tumors display a similar pattern of increasing total excess deaths over time due to increases in deaths occurring $\geq 10.0$ years from diagnosis (Figure 2 ). In $2016,36.2 \%$ of excess deaths due to germ cell tumors occurred $\geq 10.0$ years from diagnosis, compared to $52.0 \%$ occurring $<5.0$ years from diagnosis. This disparity was less pronounced among osteosarcoma patients with $13.4 \%$ of excess deaths occurring $\geq 10.0$ years from diagnosis and $77.6 \%$ occurring $<5.0$ years from diagnosis.

\section{Discussion}

Without question, there have been impressive advances over the past five decades in not only the treatment of children/adolescents diagnosed with cancer but also in our understanding of the long-term consequences associated with curative therapy.[5] Our data demonstrating a decline in excess deaths $<5$ years post-diagnosis for several tumor groups reflect these improvements and document the increased lifespan of childhood/adolescent cancer patients. However, the total annual number of excess deaths among AML, NHL, and Ewing's sarcoma declined only modestly or plateaued from 1985 to 2016 due to increasing excess deaths occurring $\geq 10$ years post-diagnosis. Further, for retinoblastoma, osteosarcoma, and germ cell tumors the total number of excess deaths is increasing, again due to the growing number of survivors at risk for life-threatening comorbidities as they move further from diagnosis. Without effective implementation of therapeutic strategies that maintain efficacy while avoiding treatment-related morbidity, plus advancements in survivorship care, this trend is likely to continue.

In summary, we demonstrate that excess deaths are an important population-based metric of the successful short and long-term treatment of childhood/adolescent cancer. As we continue to improve the overall 5-year survival for childhood/adolescent cancers, the number of cancer survivors at risk for treatment-related late effects will continue to increase limiting the overall improvement in mortality from childhood/adolescent cancer. 


\section{FUNDING}

This work was supported by the National Cancer Institute at the National Institutes of Health (grant numbers K00CA222742 (A.M.W.), CA21765, Dr. Charlie Roberts, PI) as well as the American Lebanese Syrian Associated Charities (ALSAC).

\section{NOTES}

Role of the Funder:

The content is solely the responsibility of the authors and does not necessarily represent the official views of the National Institutes of Health. The funding organization had no role in the design and conduct of the study; collection, management, analysis, and interpretation of the data; preparation, review or approval of the manuscript; and decisions to submit the manuscript for publication.

Author Disclosures:

The authors declare no conflicts of interested.

\section{DATA AVAILABILITY}

The data underlying this article are available US National Cancer Institute's Surveillance, Epidemiology, and End Results 9-registries which can be accessed at: https://seer.cancer.gov/ 
medRxiv preprint doi: https://doi.org/10.1101/2020.12.24.20248729; this version posted December 27, 2020. The copyright holder for this

\section{References}

1. Smith MA, Altekruse SF, Adamson PC, et al. Declining childhood and adolescent cancer mortality. Cancer 2014;120:2497-2506.

2. Bhakta N, Liu Q, Ness KK, et al. The cumulative burden of surviving childhood cancer: an initial report from the St Jude Lifetime Cohort Study (SJLIFE). The Lancet 2017;390:2569-2582.

3. Hudson MM, Ehrhardt MJ, Bhakta N, et al. Approach for classification and severity grading of long-term and late-onset health events among childhood cancer survivors in the St. Jude lifetime cohort. Cancer Epidemiology Biomarkers and Prevention 2017;26:666-674.

4. Enderlein G. Cox, D. R.; Oakes, D.: Analysis of Survival Data. Chapman and Hall, London New York 1984, 201 S., $£$ 12,-. Biometrical Journal 1987;29(1):114-114.

5. Robison LL, Hudson MM. Survivors of childhood and adolescent cancer: Life-long risks and responsibilities. Nature Reviews Cancer 2014;14:61-70.

6. Orgel E, Zung L, Ji L, et al. Early cardiac outcomes following contemporary treatment for childhood acute myeloid leukemia: a North American perspective. Pediatr Blood Cancer 2013;60(9):1528-33.

7. Wilhelmsson $M$, Glosli $H$, Ifversen $M$, et al. Long-term health outcomes in survivors of childhood AML treated with allogeneic HSCT: a NOPHO-AML Study. Bone Marrow Transplant 2019;54(5):726-736.

8. Leung W, Hudson MM, Strickland DK, et al. Late effects of treatment in survivors of childhood acute myeloid leukemia. J Clin Oncol 2000;18(18):3273-9.

9. Ward E, DeSantis C, Robbins A, et al. Childhood and adolescent cancer statistics, 2014. CA Cancer J Clin 2014;64(2):83-103.

10. Kleinerman RA, Yu CL, Little MP, et al. Variation of second cancer risk by family history of retinoblastoma among long-term survivors. J Clin Oncol 2012;30(9):950-7.

11. Fung C, Sesso HD, Williams AM, et al. Multi-institutional assessment of adverse health outcomes among north American testicular cancer survivors after modern cisplatin-based chemotherapy. Journal of Clinical Oncology 2017;35:1211-1222.

12. Kerns SL, Fung C, Monahan PO, et al. Cumulative burden of morbidity among testicular cancer survivors after standard cisplatin-based chemotherapy: A multi-institutional study. Journal of Clinical Oncology 2018;36:1505-1512.

13. Hale GA, Marina NM, Jones-Wallace $D$, et al. Late effects of treatment for germ cell tumors during childhood and adolescence. J Pediatr Hematol Oncol 1999;21(2):115-22. 
medRxiv preprint doi: https://doi.org/10.1101/2020.12.24.20248729; this version posted December 27, 2020. The copyright holder for this preprint (which was not certified by peer review) is the author/funder, who has granted medRxiv a license to display the preprint in perpetuity.

All rights reserved. No reuse allowed without permission.

Figure 1: Decreasing and Stable Patterns of Excess Deaths Over Time. Estimated number and proportion of excess deaths among A) acute myeloid leukemia, B) non-Hodgkin lymphoma, and C) Ewing's sarcoma cases diagnosed 0-19 years of age in the US between 1975-2016 according to calendar year of death and interval from diagnosis to death.

Figure 2: Increasing Patterns of Excess Deaths Over Time. Estimated number and proportion of excess deaths among $A$ ) retinoblastoma, $B$ ) osteosarcoma, and $C$ ) germ cell tumor cases diagnosed 0-19 years of age in the US between 1975-2016 according to calendar year of death and interval from diagnosis to death. 
medRxiv preprint doi: https://doi.org/10.1101/2020.12.24.20248729; this version posted December 27, 2020. The copyright holder for this preprint (which was not certified by peer review) is the author/funder, who has granted medRxiv a license to display the preprint in perpetuity.

All rights reserved. No reuse allowed without permission.

Table 1: Diagnosis groups and their corresponding International Classification of Childhood Cancer ICCC Record ICD-0-3/WHO 2008 classification.

Acute Lymphoblastic Leukemia

I(a) Lymphoid leukemias

II(d) Miscellaneous lymphoreticular neoplasms

Acute Myeloid Leukemia

I(b) Acute myeloid leukemias

Hodgkin lymphoma

II(a) Hodgkin lymphomas

Non-Hodgkin lymphoma

II(b) Non-Hodgkin lymphomas (except Burkitt lymphoma)

II(c) Burkitt lymphoma

II(e) Unspecified lymphomas

Central Nervous System Tumors

III(a) Ependymomas and choroid plexus tumor

III(b) Astrocytomas

III(c) Intracranial and intraspinal embryonal tumors

III(d) Other gliomas

III(e) Other specified intracranial/intraspinal neoplasms

III(f) Unspecified intracranial and intraspinal neoplasms

X(a) Intracranial \& intraspinal germ cell tumors

Neuroblastomas

IV(a) Neuroblastoma and ganglioneuroblastoma

IV(b) Other peripheral nervous cell tumors

Rhabdomyosarcomas

IX(a) Rhabdomyosarcomas

Soft Tissue Sarcomas

IX(b) Fibrosarcomas, peripheral nerve \& other fibrous

IX(c) Kaposi sarcoma

IX(d) Other specified soft tissue sarcomas

IX(e) Unspecified soft tissue sarcomas

Retinoblastoma

V Retinoblastoma

Renal Cancers

$\mathrm{VI}(\mathrm{a})$ Nephroblastoma and other nonepithelial renal tumors

Liver Cancers

VII(a) Hepatoblastoma

Osteosarcomas

VIII(a) Osteosarcomas

Ewing's Sarcoma

VIII(c) Ewing tumor and related sarcomas of bone

Germ Cell Tumors

$X(b)$ Extracranial \& extragonadal germ cell tumors

$X(c)$ Malignant gonadal germ cell tumors

X(d) Gonadal carcinomas

$\mathrm{X}(\mathrm{e})$ Other and unspecified malignant gonadal tumors 
248729: this version posted December 27, 2020. The copyriaht holder for this preprint (which was not certified by peer review) is the author/funder, who has granted medRxiv a license to display the preprint in perpetuity.

\section{Interval From Diagnosis}

\section{$<5.0$ years \\ 5.0-9.9 years \\ $\geq 10.0$ years}

\section{A) Acute Myeloid Leukemia}
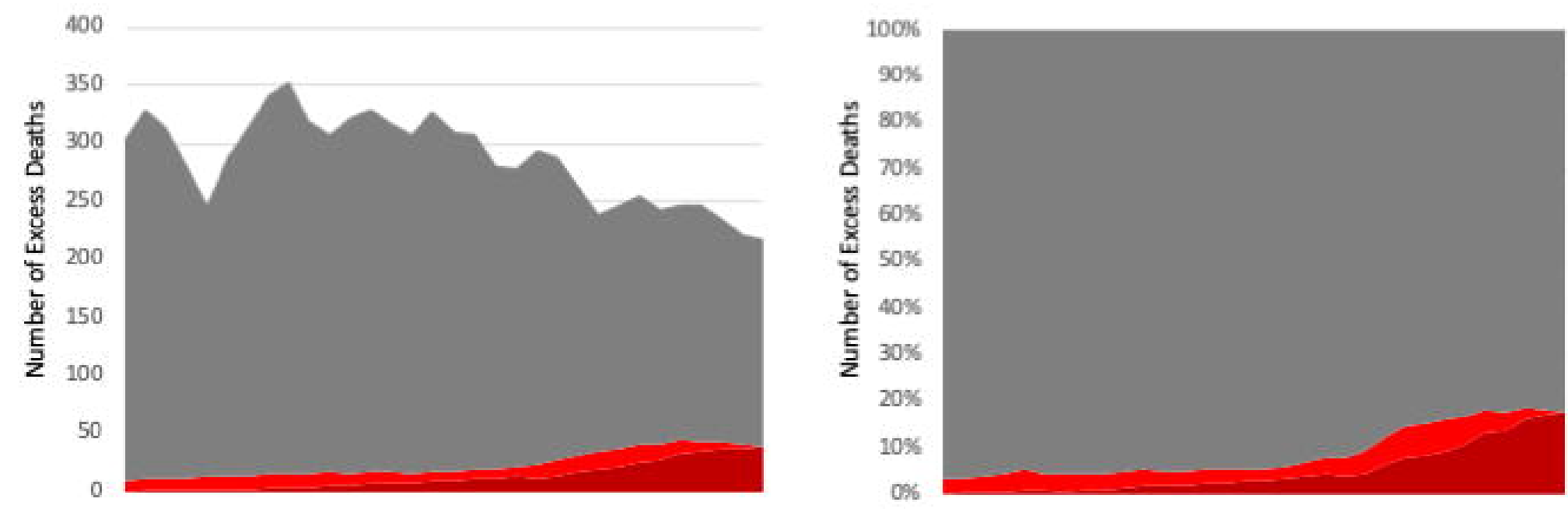

\section{B) Non-Hodgkin Lymphoma}
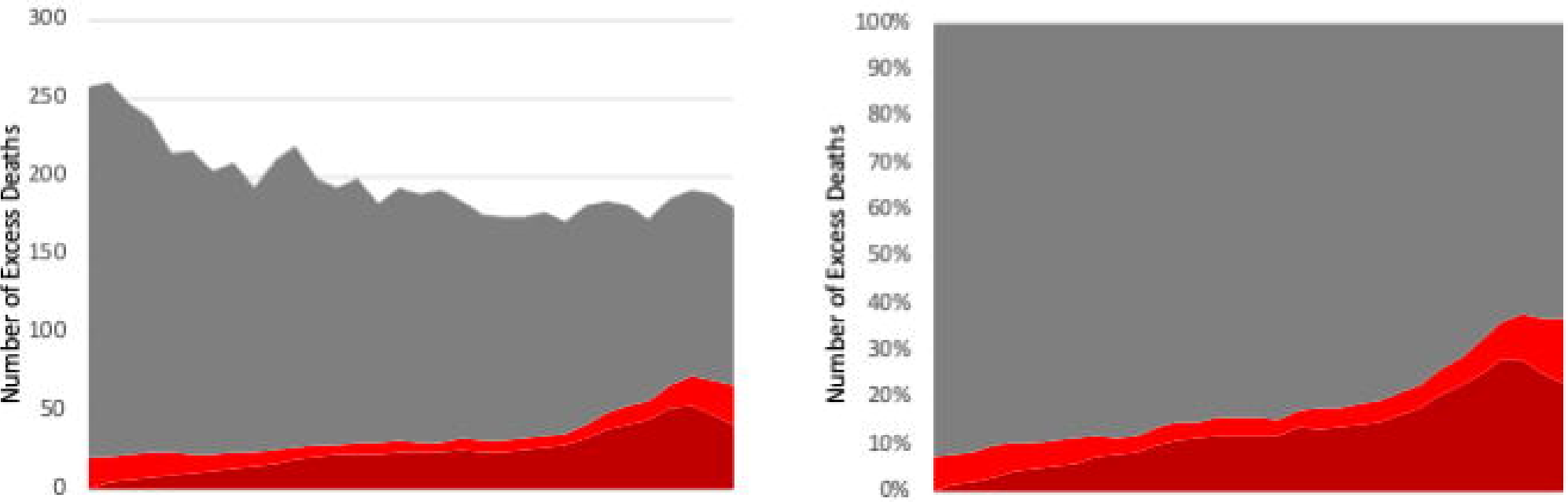

\section{C) Ewing's Sarcoma}
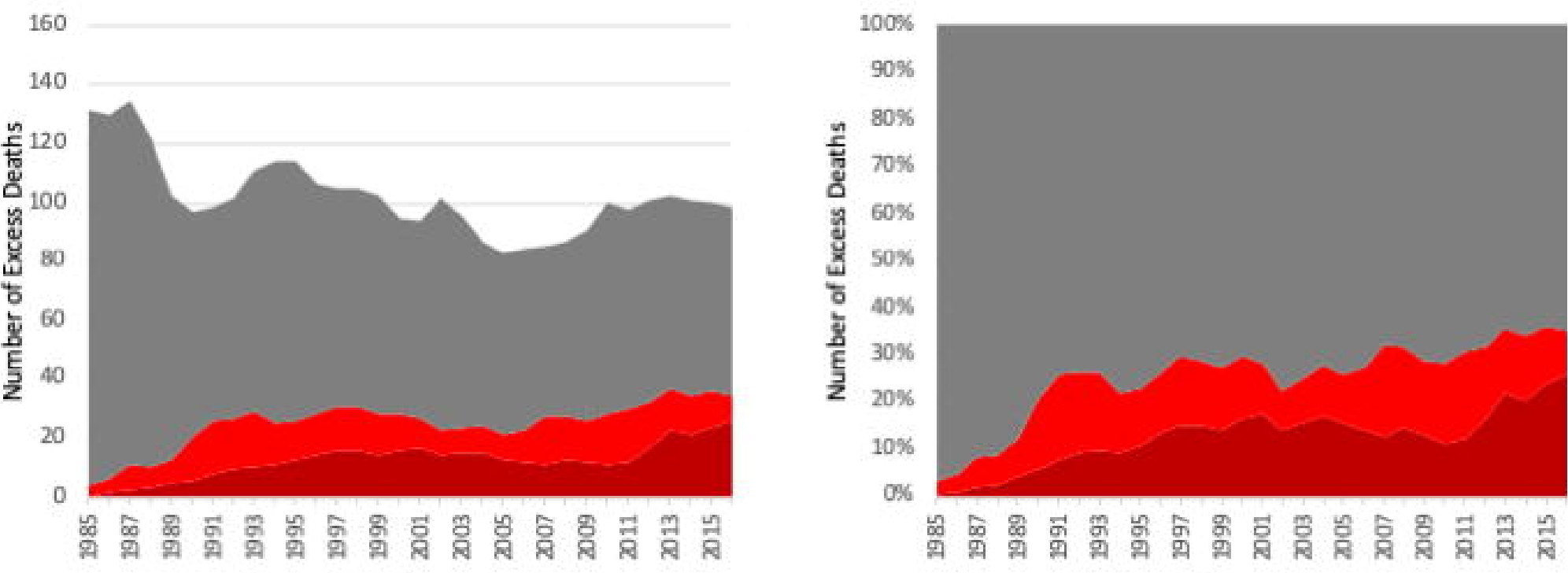
2420248729 ; this version posted December 27, 2020. The copyright holder for this preprint (which was not certified by peer review) is the author/funder, who has granted medRxiv a license to display the preprint in perpetuity. All rights reserved. No reuse allowed without permission.

\section{Interval From Diagnosis}

\section{A) Retinoblastoma}
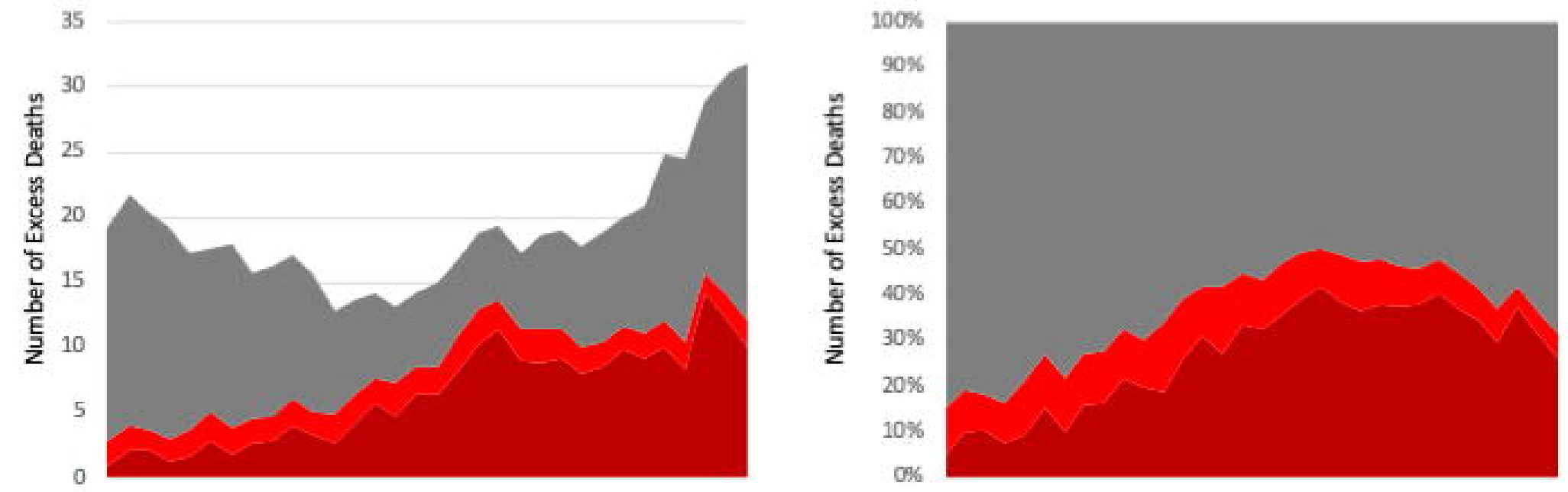

\section{B) Osteosarcoma}
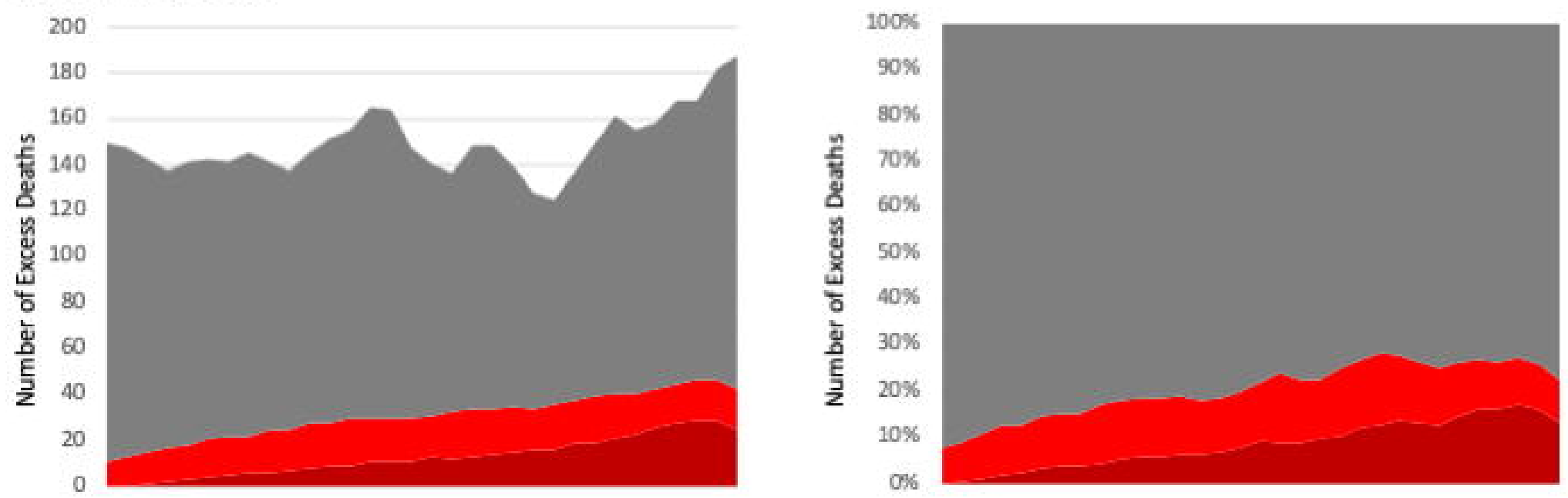

\section{C) Germ Cell Tumors}
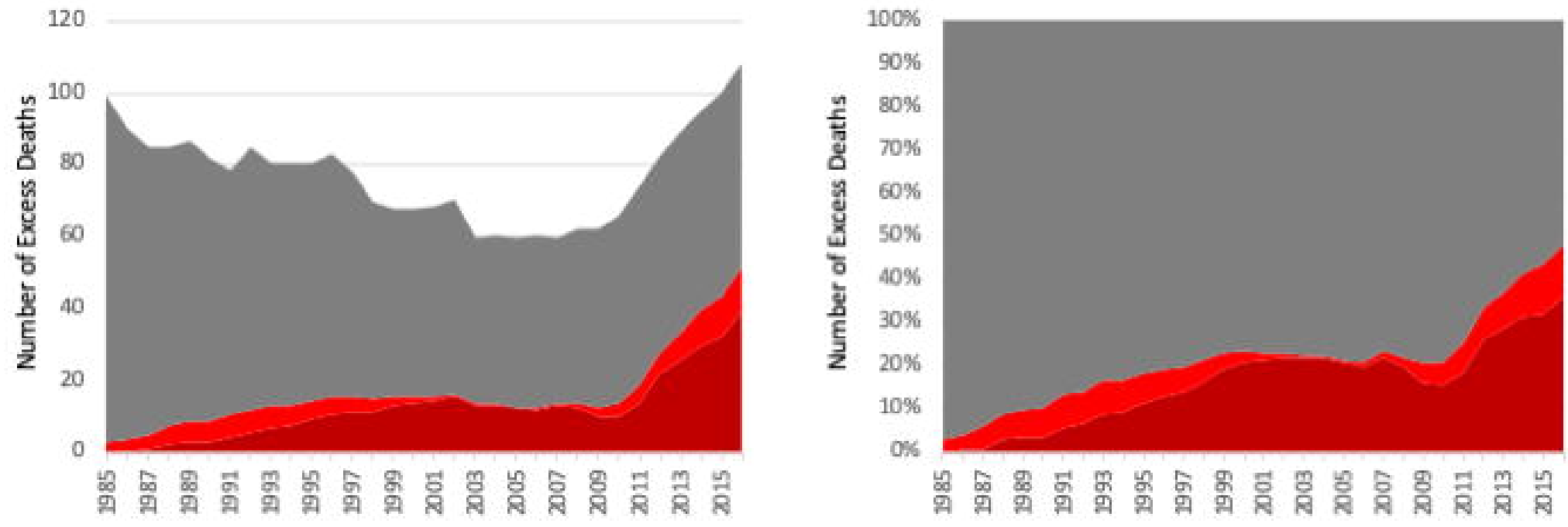